ORIGINAL ARTICLE

\title{
The prevalence of MADH4 and BMPR IA mutations in juvenile polyposis and absence of BMPR2, BMPR1B, and ACVR 1 mutations
}

\author{
J R Howe, M G Sayed, A F Ahmed, J Ringold, J Larsen-Haidle, A Merg, F A Mitros, C A Vaccaro, \\ G M Petersen, F M Giardiello, S T Tinley, L A Aaltonen, H T Lynch
}

J Med Genet 2004;41:484-491. doi: 10.1136/jmg.2004.018598

See end of article for authors' affiliations

Correspondence to:

Dr J R Howe, Department of Surgery, $4644 \mathrm{JCP}$

University of lowa College of Medicine, 200 Hawkins Drive, lowa City, IA 52242-1086, USA; james-howe@uiowa.edu

Revised version received 26 February 2004 Accepted for publication 27 February 2004

\begin{abstract}
Background: Juvenile polyposis (JP) is an autosomal dominant syndrome predisposing to colorectal and gastric cancer. We have identified mutations in two genes causing JP, MADH4 and bone morphogenetic protein receptor 1A (BMPRIA): both are involved in bone morphogenetic protein (BMP) mediated signalling and are members of the TGF- $\beta$ superfamily. This study determined the prevalence of mutations in MADH4 and BMPRIA, as well as three other BMP/activin pathway candidate genes in a large number of JP patients.

Methods: DNA was extracted from the blood of JP patients and used for PCR amplification of each exon of these five genes, using primers flanking each intron-exon boundary. Mutations were determined by comparison to wild type sequences using sequence analysis software. A total of $77 \mathrm{JP}$ cases were sequenced for mutations in the MADH4, BMPRIA, BMPRIB, BMPR2, and/or ACVR1 (activin A receptor) genes. The latter three genes were analysed when $M A D H 4$ and BMPRIA sequencing found no mutations. Results: Germline MADH4 mutations were found in 14 cases $(18.2 \%)$ and BMPRIA mutations in 16 cases (20.8\%). No mutations were found in BMPR 1B, BMPR2, or ACVR1 in 32 MADH4 and BMPR1A mutation negative cases.

Discussion: In the largest series of JP patients reported to date, the prevalence of germline MADH4 and BMPR IA mutations is approximately $20 \%$ for each gene. Since mutations were not found in more than half the JP patients, either additional genes predisposing to JP remain to be discovered, or alternate means of inactivation of the two known genes are responsible for these JP cases.
\end{abstract}

$\int_{\text {to }}^{\mathrm{u}}$ uvenile polyposis (JP) is an autosomal dominant hamartomatous polyposis syndrome which predisposes to gastrointestinal cancer. The prevalence is approximately one in 100000 persons $^{1}$ and affected individuals develop primarily colorectal and sometimes upper GI juvenile polyps. Juvenile polyps are characterised by normal epithelium and a lamina propria markedly expanded by dilated glands, abundant stroma, and an inflammatory infiltrate. The GI cancers which develop in JP patients are epithelial and the mechanism by which polyps transform into cancers remains unknown.

Significant progress has been made in our knowledge of the genes predisposing to JP. In 1998, a locus for JP was mapped to chromosome $18 \mathrm{q} 21$ by genetic linkage in a large JP family from Iowa. Subsequently, MADH4 (SMAD4, DPC4) germline mutations were identified in all affected members of this kindred as well as four other pedigrees. ${ }^{2}$ This finding was later confirmed by several investigators, ${ }^{3-6}$ but $M A D H 4$ mutations have only accounted for a fraction of JP cases. ${ }^{3}$ In 2001, a second locus for JP was localised to chromosome 10q22-23 by genetic linkage in four North American JP kindreds, and germline mutations were found in the bone morphogenetic protein receptor IA $(B M P R I A)$ gene in all affected members of these families. ${ }^{8}$ This finding was subsequently confirmed in other JP cases. ${ }^{910}$ However, the relative contribution of each of these genes in a large series of JP patients remains to be determined.

Since both genes known to predispose to JP are members of the TGF- $\beta$ superfamily, another unanswered question is whether mutations of other genes in these pathways also cause JP. To date, studies examining JP cases for mutations of MADH1, MADH2, MADH3, MADH5, and MADH7 have been negative. ${ }^{11}{ }^{12} \mathrm{JP}$ may possibly result from alteration of BMPmediated signalling pathways, since these both require BMPRIA and MADH4, and, therefore, alterations of other genes in the BMP pathway might also play a role in JP predisposition. It is of interest that bone morphogenetic protein receptor type II (BMPR2) is mutated in the germline of patients with familial pulmonary hypertension ${ }^{13}$ and mutations in the type I receptor homologue in the activin pathway $(A C V R I)$ predispose to hereditary hemorrhagic telangiectasia (HHT). ${ }^{14} 15 \mathrm{JP}$ patients sharing features with these disorders have been described ${ }^{16-18}$ and, therefore, $B M P R 2, A C V R 1$, and the other BMP type I receptor, $B M P R I B$, might also be plausible candidate genes for JP. In this study, we set out to determine the prevalence of $M A D H 4$ and BMPRIA mutations in JP, and whether JP patients without germline mutations in these two genes have mutations in BMPR1B, BMPR2, or ACVR1.

\section{METHODS}

\section{Patients}

The project was approved by the University of Iowa Institutional Review Board. After informed consent was obtained from each patient or guardian, blood was drawn and patients completed medical history questionnaires. Medical records were obtained and reviewed, and the standard criteria for the diagnosis of JP were used, which included: 1) more than five juvenile polyps of the colorectum;

Abbreviations: $B M P$, bone morphogenetic protein; BMPRIA, bone morphogenetic protein receptor 1A gene; CS, Cowden syndrome; HHT, hereditary hemorrhagic telangiectasia; JP, juvenile polyposis; MHI, Mad Homology 1 
2) juvenile polyps throughout the GI tract; or 3) any number of juvenile polyps with a family history of $\mathrm{JP}^{19}{ }^{19}$ Specific features suggestive of Peutz-Jeghers syndrome, Cowden syndrome (CS), Bannayan-Ruvalcaba-Riley syndrome, and Gorlin syndrome were sought out from medical records and questionnaires and patients with these characteristics were excluded from this study. DNA was extracted from whole blood using a salting-out method ${ }^{20}$ and then quantitated by spectrophotometry.

\section{Defining intron-exon boundaries}

The cDNA sequences of BMPRIB (Alk-6), BMPR2, and ACVRI (Alk-1) were retrieved from GenBank and segments of each were then searched using the BLAST algorithm against the draft version of the human genome sequence ${ }^{21}$ and Celera genome sequences. ${ }^{22}$ The intron-exon boundaries of each gene were defined by comparison of these sequences and then primers were designed from intronic sequence flanking each exon using the Primer3 program.

\section{BMPR IB (Alk-6) primers}

Exons 1-3 were identified upon the BAC clone 2025F7 (acc. no. AP001950), exon 4 on BAC RPl1-59Il6 (acc. no. AC011818), and exons 6-10 from BAC 2212D22 (acc. no. AP001969). The primers selected using the Primer3 program which were found to work well for amplification and sequencing were (capital letters represent nucleotides within exons, non-capitals within introns): exon 1-Alk6-la: cccca cagatgcctaactct, Alk6-1b: gcctacagttgcatagttgaaaaa (269 bp product); exon 2-Alk6-2a: acacattctgtttctcactttgc, Alk6-2b: ttgcttgaaacttgttggaaa (204 bp); exon 3-Alk6-3a: gactttgaaa tttggaagaaactca, Alk6-3b: ctccagcagtggaaagtggt (266 bp); exon 4-Alk6-4a: tctttcacattttgtgcgtga, Alk6-4b: gaaacactaa caggcaaaagca (294 bp); exon 5-Alk6-5a: ttttactccatcattgca tttca, Alk6-5b: gctttctccttgtccagtgc (302 bp); exon 6-Alk6-6a: aacaaatctgtagcgctgtgaa, Alk6-6b: ggaaagctaggaaacctgaa (292 bp); exon 7-Alk6-7a: tttggaaaacactaaaccttttca, Alk6-7b: cctagaagcactgcgctaca (416 bp); exon 8-Alk6-8a: tcgtttttgtt gccctcttc, Alk6-8b: gcactatgactgcatcaacaga (370 bp); exon 9Alk6-9a: gcacttttcctttgagaactgtg, Alk6-9b: ccatcaccatcaccat caaa (339 bp); exon 10-Alk6-10a: ccagccttgcagatgataca, Alk6-10b: tctgcccacaaacagaagag (234 bp).

\section{BMPR 2 primers}

Exons 1 and 3-7 were found on BAC clone RP11-68606 (acc. no. AC064836) and exons 8-13 on BAC RPll-345Nl2 (acc. no. AC009960). Exon 2 was not found in the human genome sequence and, therefore, primers could only be chosen from within this exon. Exon 12 was very large (1280 bp) and required four primer pairs to span this sequence. The primers chosen were: exon 1-BMPR2-lc: tcttttctttgcctcctga, BMPR2ld: ggcgatttccetggaagg (288 bp); exon 2-BMPR2-2a: tagCTTCGCAGAATCAAGAAC, BMPR2-2b: tgcCTTGTTTTAC AAGATTTATGTC (177 bp); exon 3-BMPR2-3a: tcctgttgatttg caaaactgt, BMPR2-3b: tgcaaatctttggagaaagga (358 bp); exon 4-BMPR2-4a: cagctttctaaagggcagtc, BMPR2-4b: aggctgggtg tattttgcat (320 bp); exon 5-BMPR2-5a: gctgctaatctttctg cagctc, BMPR2-5b: gaatgaagtcactgttccaggtc (273 bp); exon 6-BMPR2-6a: gcaacagagagctgtagcatt, BMPR2-6b: tacaggca taagccaccaca (39l bp); exon 7-BMPR2-7a: catggaatcctagcc tatttgc, BMPR2-7b: cccacatgagtgtcaatttca (264 bp); exon 8-BMPR2-8a: tcatttcatgttcaatagtccttt, BMPR2-8b: cacacctgg ccagtagatgtt (298 bp); exon 9-BMPR2-9a: tgttcttcagaatatgc tacgttctc, BMPR2-9b: gaagatataactgcttcacttcaaaaa (258 bp); exon 10-BMPR2-10a: gcctgaaggggatgaaaaa, BMPR2-10b: ggcattaggcaactccaaaa (388 bp); exon 11-BMPR2-11a: catgtgg taaactgaaaagctca, BMPR2-1 lb: ttctttgttgggtctcagtttct (310 bp); exon 12-BMPR2-12a: aaattggagagacagtttgtca, BMPR2-12b: TTCATCTGGGTATGGCATCTC (391 bp); BMPR2-12c: CACA
GGACTCACGCCAAGTA，BMPR2-12d: ATCAAACATGCTTGG CCATT (351 bp); BMPR2-12e: CTGGACAGCAGGACTT CACA, BMPR2-12f: CTTGGGCCCTATGTGTCACT (381 bp); BMPR2-12g: CCACAACCCAATATGCCAAT, BMPR2-12h: ccccaaaagacacacaggag (449 bp); exon 13-BMPR2-13a: cacctcctgagacattggt, BMPR2-13b: gggtgctgacaggaggataa (458 bp).

\section{ACVR (Alk-1) primers}

All exons were found on the Celera chromosome 12 scaffold segment GA_x2HTBL3Q5WG. ${ }^{22}$ The nine exons corresponded to 1512 bp in cDNA, which were distributed over 8428 bp in genomic DNA. The primers used were: exon l-Alkl-la: gctgtcacacttcatggctct, Alkl-lb: cccagcttctcaagttcagc (216 bp); exon 2-Alkl-2a: taggacagaaatgggtgtcg, Alkl-2b: ccagagcat gagaggaaagg (407 bp); exon 3-Alk1-3a: gggagctgacctagtgg aag, Alkl-3b: tcctatctgcccctcctaca (308 bp); exon 4-Alkl-4a: tcccaggtcgaggatagaga, Alk1-4b: gagagccttggtcctcatc (216 bp); exon 5-Alkl-5a: tgtgtgcccagtgtgtaacc, Alkl-5b: aacttgagccet gagtgcag (255 bp); exon 6-Alkl-6a: acgactccagcctccttag, Alk1-6b: ctccgccacctgtgaag (383 bp); exon 7-Alkl-7a: ttctctcagtccccaccttg, Alkl-7b: gctgattcccetttccctac (320 bp); exon 8-Alk1-8a: tggtattgggcctccttaga, Alk1-8b: ggcctcagaca caagttcct (272 bp); exon 9-Alk1-9-5': tctcctctgcacctctctcccaa, Alk1-9-3': ctgcaggcagaaaggaatcaggtgct (197 bp).

\section{Sequencing}

DNA from each exon was amplified by PCR using intronic primers as previously described for $M A D H 4^{2}$ and $B M P R I A .^{8}$ The primers developed for BMPRIB, BMPR2, and ACVRI are described above. PCR products were purified from $2 \%$ agarose gels using Qiaquick columns (Qiagen), quantitated, then cycle-sequenced using ABI-Prism dye terminators (Applied Biosystems) and one of the PCR primers. Sequences were determined using a Model 377 ABI Sequencer. Patient sequences were compared to wild type sequences using the Sequencher software (GeneCodes) and alterations from the wild type sequence were confirmed by sequencing in the opposite direction. When available, other family members were sequenced for the mutated exon to determine whether the same changes were present. Point mutations which did not change an amino acid were assumed to be silent polymorphisms.

\section{RESULTS}

\section{Patients}

DNA from a total of 77 different JP families and sporadic cases was sequenced. The majority of cases were referred from outside physicians and genetic counsellors within the United States, with additional cases coming from Canada, South America, and Europe. Seven Finnish JP cases in which we previously reported MAHD4 sequencing results are not counted in this total, but are considered in later discussions of combined studies. ${ }^{2}$ Other patients previously reported from our laboratory were included. ${ }^{2}{ }^{23}$ The MADH4 and BMPRIA genes were sequenced first in all cases, although BMPRIA was not sequenced in six cases in which $M A D H 4$ mutations had already been established. The PTEN gene was also sequenced in the first 40 cases (except for four in which MADH4 mutations had been found), but this was discontinued thereafter because these mutations were considered to represent misdiagnoses of JP for CS. ${ }^{7} B M P R 1 B, B M P R 2$, and $A C V R I$ were sequenced in a total of $32 M A D H 4, B M P R I A$, and PTEN mutation negative cases.

\section{Results of sequencing}

Germline MADH4 mutations were found in 14 of 77 (18.2\%) JP cases (table 1). These consisted of eight deletions and six substitutions. All deletions were predicted to result in 
premature stop codons, and of the six substitutions, one was a nonsense mutation and five were missense mutations. These mutations were distributed across six of the 11 MADH4 exons. In six cases, additional affected family members were available for sequencing and the proband mutation was found in the affected kindred members.

BMPRIA mutations were identified in 16 of 77 (20.8\%) JP cases (table 2). These included six deletions and 10 substitutions. All deletions predicted for premature stop codons, and four substitutions were nonsense and six were missense mutations. These mutations were found in eight of 11 BMPRIA exons. Additional affected family members were available in six cases and the proband mutation was found in the affected kindred members.

PTEN mutations were found in only one patient, who, in retrospect, had features most consistent with Cowden syndrome. ${ }^{7}$ This mutation was an insertion of an additional adenine in a stretch of four adenines in exon 8 (87linsA), which would lead to a premature stop at codon 297. No mutations were found upon sequencing $B M P R 1 B, B M P R 2$, or ACVRl genes in 32 patients (table 3 ).

\section{DISCUSSION}

Mutations in members of the TGF- $\beta$ pathway have been implicated in the development of colon cancer, including those affecting the type I receptor, ${ }^{24}$ type II receptor, ${ }^{25}$ and $M A D H 4 .{ }^{26}$ The finding that germline mutations in $M A D H 4$ were responsible for a proportion of JP cases ${ }^{2}$ raised the possibility that mutations of other members of the TGF- $\beta$ pathway could be responsible for JP. The discovery that germline mutations in BMPRIA also caused JP suggested that disruption of BMP-mediated signalling rather than TGF- $\beta$ could be responsible for this unusual phenotype predisposing to colon cancer. The BMP pathway is within the TGF- $\beta$ superfamily, which encompasses the TGF- $\beta$, BMP, activin, and inhibin pathways. ${ }^{27}$ All share $M A D H 4$ as the common intracellular mediator of signal transduction. In these pathways, the respective ligands bind to specific type II receptors, which then activate specific type I receptors. The type I receptors phosphorylate MAD proteins (MADH2 and MADH3 for TGF- $\beta$; MADH1, MADH5, and MADH8 for BMP), which then form oligomers with MADH $4,{ }^{28}$ migrate to the nucleus, and regulate the transcription of specific genes by binding to particular sequences in conjunction with DNA binding proteins. ${ }^{29}$

This study represents the largest single series of JP patients examined for MADH4 or BMPRIA mutations, and, as such, gives an accurate estimate of the prevalence of these alterations. We found an overall mutation rate of $18.2 \%$ for MADH4 and $20.8 \%$ for BMPRlA, suggesting that either additional JP genes remain to be discovered, or alternate methods of inactivation of these genes (which are not detected by sequencing) may be responsible for JP. With respect to correlation of mutations with phenotype, we have previously reported that $89 \%$ (17/19) of MADH4 and BMPRIA mutation positive (MUT+) cases and 63\% (17/27) of mutation negative (MUT-) cases were familial $(\mathrm{p}=0.09)$, and $89 \%$ (17) 19) of MUT+ and 52\% (13/25) of MUT- cases had a family history of GI cancer $(p=0.01) .{ }^{23}$ Interestingly, the incidence of a family history of upper GI juvenile polyps was $86 \%(6 / 7)$ in $M A D H 4$ mutation positive cases, $10 \%$ in BMPRIA mutation positive cases, and $23 \%(5 / 22)$ in mutation negative cases. Friedl et al also found that four of seven MADH4 mutation positive cases, only one of five cases with BMPRIA mutations and two of 17 MUT- cases had gastric polyposis. ${ }^{10}$ It therefore appears that $M A D H 4$ mutations predispose to generalised JP, while those cases which are $M A D H 4$ mutation negative are more likely to represent juvenile polyposis coli, a JP subtype with polyps involving only the colorectum. ${ }^{30}$

Combining the present data with our previous reports ${ }^{27}$ and those of others, ${ }^{561012}$ a total of 26 different MADH4 mutations have been found in JP patients (fig 1). Friedl et al described mutations in seven of $29(24 \%) \mathrm{JP}$ cases, ${ }^{10} \mathrm{Kim}$ et al in three of five $(60 \%)$ Korean JP cases, ${ }^{5}$ Woodford-Richens in five of $24(21 \%)$ cases, ${ }^{6}$ and Howe et al and Roth et al in five of seven Finnish kindreds. ${ }^{2}{ }^{12}$ If these studies are combined with the current series, taking into account three kindreds in common, ${ }^{2}{ }^{12}$ then the total prevalence of MADH4 mutations is $22.7 \%$ (32 of 141 cases). These mutations consisted of 15 deletions, two insertions, and 15 substitutions (five nonsense, 10 missense). No splice site mutations have been described to date. Three mutations have been found in multiple patients. The 1244delACAG mutation has been reported in a total of six familial cases (four included in the present series ). ${ }^{2}{ }^{4}$ In depth haplotype analysis in four of these kindreds revealed no evidence for a common ancestor, suggesting this region of the gene is a mutational hotspot. ${ }^{31}$ Another common mutation was 1162C $>\mathrm{T}$ (E388X), described in one of our families and also in a sporadic Korean case with generalised JP. Lastly, there were four different substitutions found in codon 361, three changing a positively-charged arginine amino acid to a neutral one (glycine, serine, cysteine) and the other to a positively-charged histidine. The R361C mutation has also been described in the colorectal cancer cell line Mx5. ${ }^{26}$ A substitution similar to the E330G in this study (changing a neutral, polar amino acid to a neutral non-polar one) has also been described in colorectal cancer (E330A).32

Of the 26 MADH4 unique mutations, only one (a deletion of nine nucleotides, amino acids 64-66) mapped to the Mad Homology 1 (MHl) domain, in a patient with extensive colonic polyposis. ${ }^{6}$ The $\mathrm{MHI}$ domain can directly bind to DNA

\begin{tabular}{|c|c|c|c|c|c|}
\hline Case & Type* & Affected sequenced (n) & Exon & Nucleotide change & Result \\
\hline$J P 23$ & Fam & 2 & 4 & 608delC & Stop 240-1 \\
\hline JP11 & Fam & 1 & 8 & $989 A>G$ & $\mathrm{E} 330 \mathrm{G}$ \\
\hline JP8 & Unk & 1 & 8 & 1037delC & Stop 383-4 \\
\hline JP47 & Fam & 2 & 8 & $1054 \mathrm{G}>\mathrm{A}$ & $\mathrm{G} 352 \mathrm{R}$ \\
\hline$J P 64$ & Fam & 1 & 8 & $1081 C>G$ & R361G \\
\hline JP66 & Fam & 1 & 8 & $1081 C>A$ & R361S \\
\hline$J P 21$ & Fam & 6 & 9 & $1162 \mathrm{C}>\mathrm{T}$ & E388X \\
\hline JP1 & Fam & 17 & 9 & 1244delACAG & Stop $435-6$ \\
\hline $\mathrm{JP2}$ & Fam & 1 & 9 & 1244delACAG & Stop $435-6$ \\
\hline $\mathrm{JP3}$ & Fam & 6 & 9 & 1244delACAG & Stop $435-6$ \\
\hline JP4 & Fam & 3 & 9 & 1244delACAG & Stop $435-6$ \\
\hline JP69 & Unk & 1 & 10 & del1343-1365 & Stop \\
\hline JP68 & Unk & 1 & 11 & $1529 \mathrm{G}>\mathrm{T}$ & G510V \\
\hline JP22 & Fam & 1 & 11 & $1588 \mathrm{delC}$ & Stop 536-7 \\
\hline
\end{tabular}




\begin{tabular}{|c|c|c|c|c|c|}
\hline Case & Type* & $\begin{array}{l}\text { Affected } \\
\text { sequenced (n) }\end{array}$ & Exon & Nucleotide change & Result \\
\hline $\mathrm{JP17}$ & Fam & 9 & 1 & 44-47delTGIT & Stop 35-6 \\
\hline JP74 & Unk & 1 & 2 & $170 C>G$ & P57R \\
\hline JP5 & Fam & 2 & 2 & $184 \mathrm{~T}>\mathrm{G}$ & Y62D \\
\hline JP72 & Unk & 1 & 3 & $233 C>T$ & T78I \\
\hline JP57 & Spor & 1 & 3 & $245 G>A$ & $\mathrm{C} 82 \mathrm{Y}$ \\
\hline JP20 & Fam & 2 & 3 & $262 \mathrm{G}>\mathrm{T}$ & E84X \\
\hline $\mathrm{JP} 46$ & Fam & 1 & 4 & $349 C>T$ & Q117X \\
\hline $\mathrm{JP1} 4$ & Fam & 1 & 4 & 353delT & Stop 122-3 \\
\hline JP53 & Fam & 1 & 6 & 673delT & Stop 259-60 \\
\hline JP16 & Fam & 8 & 7 & $715 \mathrm{C}>\mathrm{T}$ & Q239X \\
\hline JP18 & Fam & 6 & 7 & $812 \mathrm{G}>\mathrm{A}$ & W271X \\
\hline JP25 & Spor & 1 & 7 & $\begin{array}{l}\text { 864-868delACTTGIVS7+1- } \\
\text { 2delgt }\end{array}$ & $\begin{array}{l}\text { Loss of exon } 7 \text { splice site; } \\
\text { stop at new codon } 292\end{array}$ \\
\hline JP19 & Fam & 5 & 8 & 961delC & Stop $321-2$ \\
\hline $\mathrm{JP43}$ & Spor & 1 & 8 & $1013 C>A$ & A338D \\
\hline JP9 & Fam & 1 & 8 & $1061 \mathrm{delG}$ & stop $363-4$ \\
\hline JP58 & Spor & 1 & 9 & $1327 \mathrm{C}>\mathrm{T}$ & R443C \\
\hline
\end{tabular}

in target genes, such as the plasminogen activator inhibitor$1 .^{33}$ Moren et al examined a G65V missense MADH4 mutant and found that it could translocate to the nucleus, activate a MAD-dependent promoter, and complex with Madh3, but had impaired DNA binding properties and decreased protein stability. ${ }^{34}$ Mutations between amino acids 43 and 135 in the $\mathrm{MHl}$ domain markedly reduce the DNA binding activity of MADH4, and this may be a mechanism by which tumours evade the growth suppressive effects of the TGF- $\beta$ superfamily. ${ }^{35}{ }^{36}$ Five of the 26 JP mutations mapped to the linker region of MADH4. One of these (831-2delAC) was within the MADH4 activating domain (SAD) in a patient with a VSD and extensive colonic polyposis. ${ }^{4}$ SAD is a 48 amino acid regulatory unit, that when mutated, still allows for other MAD protein and transcription factor binding, but not activation of transcription. ${ }^{37}$ The remaining mutations all map to the MH2 domain of MADH4, which is important in directing transcriptional responses. ${ }^{38}$ The majority of $M A D H 4$ mutations thus far described in diverse human tumours are found in the MH2 domain, such as eight of 10 mutations described in pancreatic cancers ${ }^{39} 40$ and nine of 11 in colorectal cancers. ${ }^{26}{ }^{32} 41$ The $\mathrm{MH} 2$ region appears to play an important role for nuclear localisation, interaction with other MADs, and transcriptional activation. ${ }^{28}{ }^{42}$ Of the different missense mutations found in the MH2 domain, five of the seven occurred at highly conserved amino acids shared in the C-terminal regions of human MADH1-5, Drosophila Mad, and C. elegans Sma2-4 proteins, and, therefore, these specific amino acids may have important structural roles. ${ }^{43}$

Since the original description of BMPRIA mutations in JP patients, ${ }^{8}$ there have been two additional reports. One described mutations in 10 of 25 (40\%) MADH4 mutation negative JP cases and one patient with either CS-like phenotype or minimal diagnostic criteria for $\mathrm{CS}^{9}$. The other found five BMPRIA mutations in $29 \mathrm{JP}$ cases $(17.2 \%) .{ }^{10}$ In the current study, we report that 16 of 77 (20.8\%) JP cases had BMPRIA mutations. In all, 31 different BMPRIA mutations have been described, two cases with a common mutation (fig 2). The best estimate of the overall prevalence of BMPRIA mutations in JP would combine the current series with that of Friedl et al (Zhou et al looked at only MADH4 negative cases and included those with CS/BRRS and CS-like features). This gives an overall BMPRIA mutation rate of $19.8 \%$ (21 of 106 cases). Of 31 unique mutations described, nine were deletions, one was an insertion, 19 were substitutions (10 missense, nine nonsense), and two were splice site mutations (not including a $7 \mathrm{bp}$ deletion at the end of exon 7, which included the $2 \mathrm{bp}$ splice acceptor site). The most commonly affected region was the protein kinase domain of the gene, where six of seven mutations in exon 7 and all eight mutations in exon 8 involved this area of the intracellular domain. There were eight mutations involving the cysteinerich region of the extracellular domain, including two nonsense mutations, five missense mutations, and one deletion. Of these missense mutations, three changed a cysteine to another amino acid (C82Y, C124R, C130R) and the other two changed a neutral amino acid with polar side chains to a negatively charged amino acid (Y62D) or to a neutral, nonpolar amino acid (T78I). There have been no mutations described in the transmembrane domain of the gene.

Several investigators have examined other $M A D$ genes for germline mutations in JP patients without MADH4 mutations. Thirty such cases were negative for mutations in $M A D H 1, M A D H 2, M A D H 3$, and $M A D H 5,{ }^{11}$ and four were negative for mutations in MADH2, MADH3, and MADH7. ${ }^{12}$ However, the involvement of other BMP receptor genes in JP, which include BMPRIB and BMPR2, has not been studied. Mutations in $B M P R 2$ have been demonstrated to cause familial primary pulmonary hypertension, a condition characterised by endothelial proliferation in the pulmonary vasculature. $^{13}$ Interestingly, there are case reports of JP patients also having pulmonary osteoarthropy, ${ }^{16}{ }^{17}$ making $B M P R 2$ a plausible candidate gene to examine in JP patients without MADH4 or BMPRIA mutations. Another type I

\begin{tabular}{|c|c|c|c|c|c|c|}
\hline & MADH4 & BMPRIA & PTEN & BMPRIB & BMPR2 & ACVR 1 \\
\hline Chromosomal locus & $18 q 21$ & $10 q 22-23$ & $10 q 22-23$ & $4 q 22-24$ & $2 q 33-34$ & $12 q 13$ \\
\hline Mutations (n) & & & & 0 & 0 & 0 \\
\hline Cases (n) & 77 & 77 & 36 & 32 & 32 & 32 \\
\hline Rate of mutation & $18.2 \%$ & $20.8 \%$ & $2.8 \%$ & $0 \%$ & $0 \%$ & $0 \%$ \\
\hline
\end{tabular}




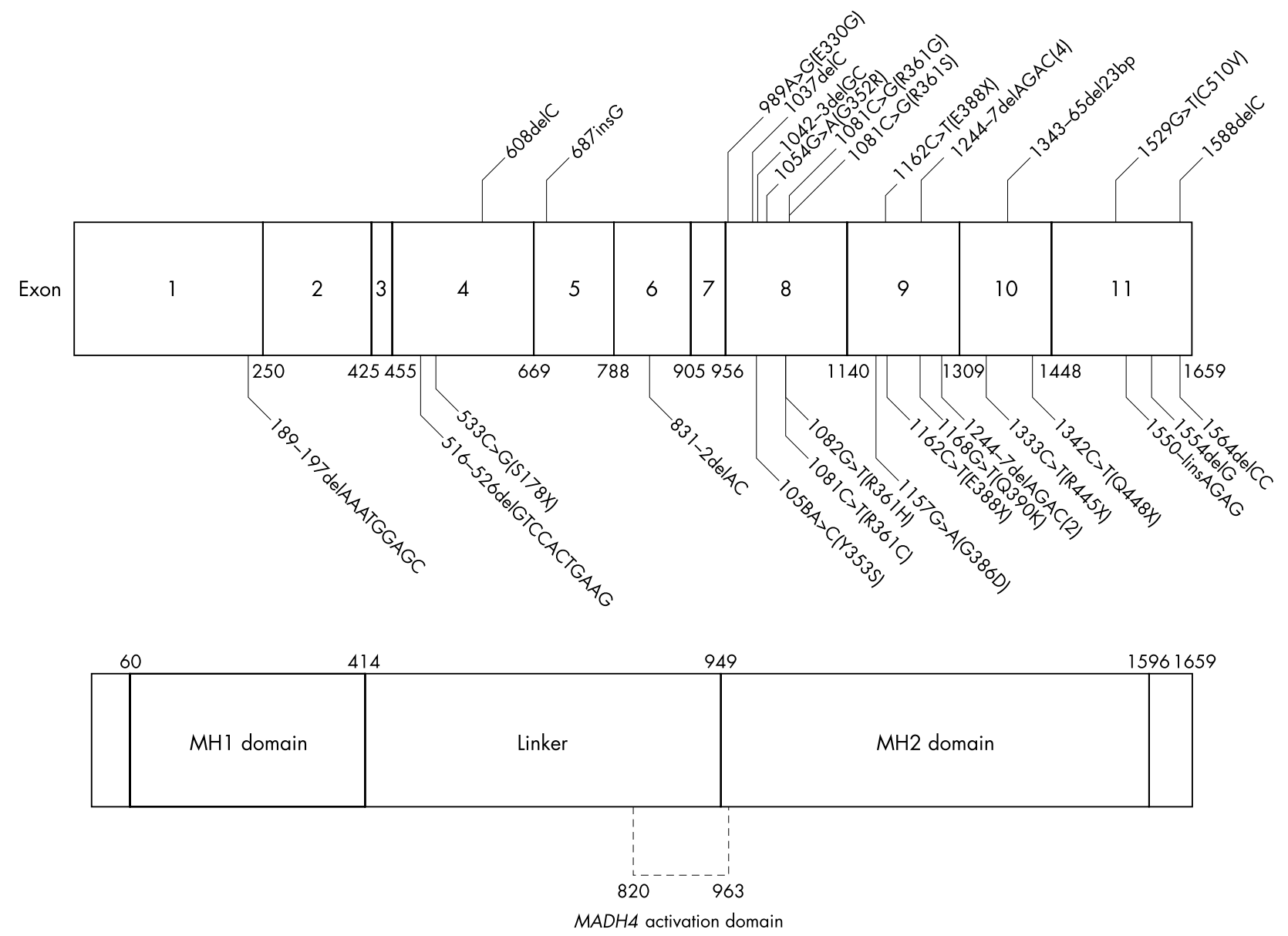

Figure 1 The upper rectangle represents the MADH4 gene, with the exons shown within the rectangle and nucleotides above and below. Lines designate mutations identified in JP cases, with those shown above each exon identified in our laboratory and those below from the reports of Friedl et al, ${ }_{1}^{4}$ Roth et al, ${ }^{12} \mathrm{Kim}$ et al, ${ }^{5}$ and Woodford-Richens et al. ${ }^{6}$ The lower rectangle represents the different known domains of the MADH4 gene.

receptor gene within the TGF- $\beta$ superfamily has also been implicated in human disease. Germline mutations in ACVRI, a type I activin receptor, have been described in hereditary hemorrhagic telangiectasia, ${ }^{15} 44$ and JP patients with pulmonary osteoarthropy have also had features reminiscent of HHT. ${ }^{17}$ In this study, 32 MADH4 or BMPRIA mutation negative JP cases were negative for mutations in $B M P R I B$, $B M P R 2$, or $A C V R 1$ by sequencing.

Only one familial JP patient in this series clearly had a history of HHT, with the proband having AV malformations of the lung requiring pulmonary resection and later embolisation. This patient had telangiectasias noted from her nose to throughout the gastrointestinal tract. She had both upper and lower GI juvenile polyps, requiring both colectomy and gastrectomy. Her daughter had pulmonary arteriovenous malformations of the left lower lobe of the lung treated by embolisation at age 18. She also had a mucinous adenocarcinoma of the rectum resected at age 22 and has had gastric, duodenal, and jejunal juvenile polyps. This patient's daughter (the grand-daughter of the proband) also had diffuse colonic polyposis, hypoalbuminemia, ascites, and digital clubbing. These individuals were found to have a substitution in exon 8 of $M A D H 4$, nucleotide $1054 \mathrm{G}>\mathrm{A}$ (G352R). Sequencing of ACVRI, BMPRIA, BMPRIB, and $B M P R 2$ were all negative for mutations in the proband. Another patient and her father have been described with cavernous transformation of the portal vein and $\mathrm{JP},{ }^{45}$ but no mutations of MADH4, BMPRIA, BMPRIB, BMPR2, or ACVRI were found in this patient. No clear history of PPH or HHT was found in the other 31 cases sequenced for BMPRIB, $B M P R 2$, or ACVRI. However, since these patients were collected from throughout North America and the evaluation of each was variable, a small number of other cases could also have had PPH or HHT. Gallione et al recently reported a series of eight patients with both JP and HHT who had germline MADH4 mutations, but no mutations of ACVRI or endoglin, confirming MADH4 as a third predisposing gene for HHT. ${ }^{46}$

A controversial issue in JP genetics is whether PTEN mutations cause JP. Two reports have described four patients with JP who had PTEN mutations, ${ }^{47}{ }^{48}$ but some of these patients could have represented cases of undiagnosed Cowden syndrome. ${ }^{49}$ Furthermore, no mutations were found by two groups who sequenced PTEN in 36 JP cases. ${ }^{50}{ }^{51}$ We found only one case of PTEN mutation in 32 MADH4 and BMPRIA mutation negative JP cases and in retrospect this patient had a family history of goitre more suggestive of Cowden syndrome than $\mathrm{JP}^{7}$. In CS, the incidence has been estimated to be $35-40 \%$ for GI polyps, $70 \%$ for fibroadenomas of the breast, $40-60 \%$ for thyroid adenomas and goitre and $99 \%$ for trichilemmomas and mucocutaneous papules. The lifetime risk is $25-50 \%$ for breast cancer and $3-10 \%$ for thyroid cancer. ${ }^{52}$ We believe that JP is not caused by PTEN mutation, but instead, some patients with CS may have only hamartomatous polyps of the GI tract identified, especially if they present with GI bleeding at a young age..$^{49}$ Therefore, we recommend that initial genetic screening in JP patients include MADH4 and BMPRIA sequencing, but if negative, PTEN sequencing may be of value to detect undiagnosed 

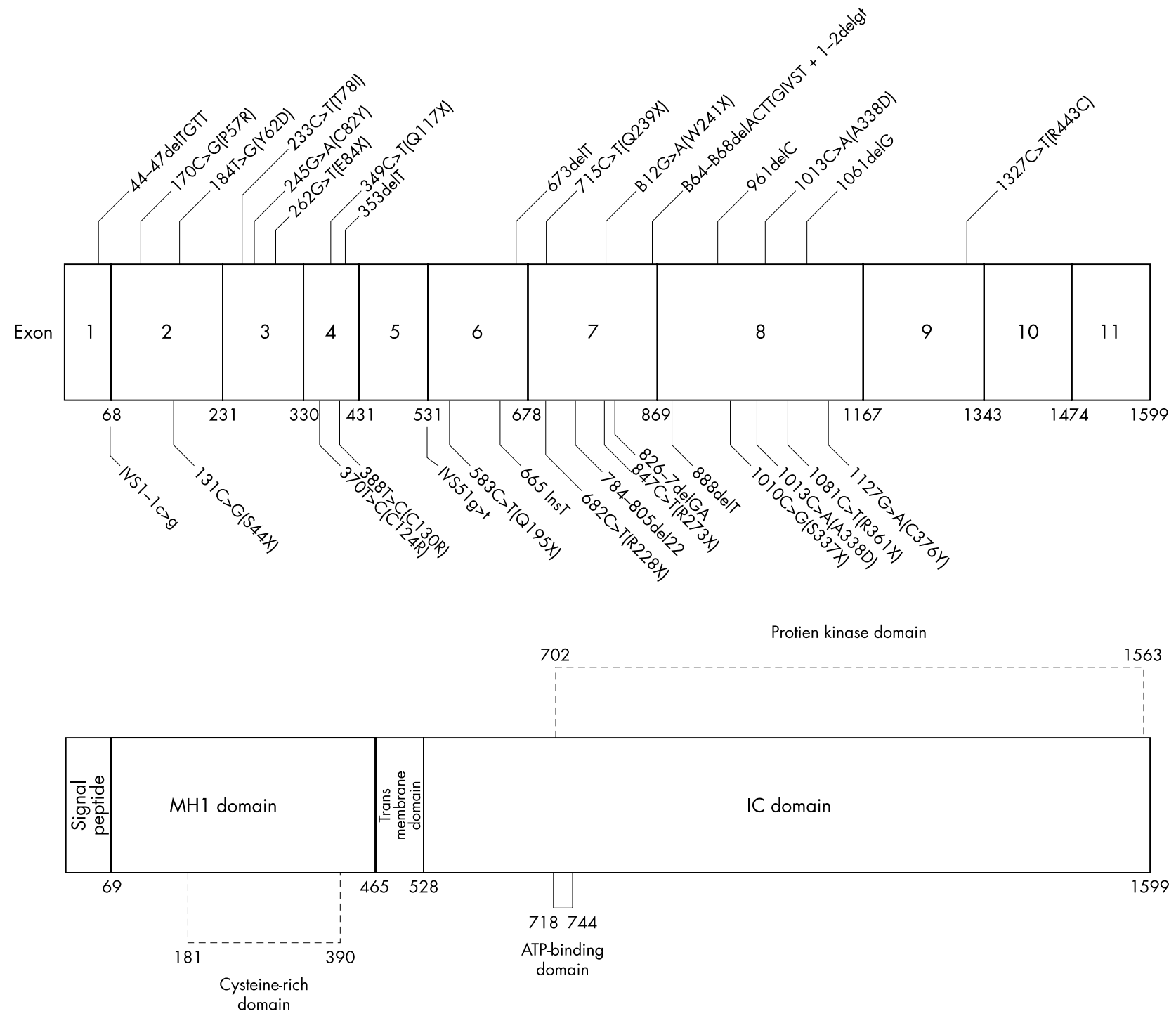

Figure 2 The upper rectangle represents the BMPRIA gene, with the exons shown within the rectangle and nucleotides above and below. Lines designate mutations identified in JP cases, with those shown above each exon identified in our laboratory and those below from the reports of Zhou et $a^{9}$ and Friedl et al. ${ }^{10}$ The lower rectangle represents the different known domains of the BMPRIA gene.

cases of CS. These patients would then potentially benefit from close screening for breast and thyroid malignancies.

In conclusion, multiple studies support a prevalence of approximately $20 \%$ each for MADH4 and BMPRIA germline mutations in JP. These data suggest there are other genes which predispose to JP and we have excluded BMPRIB, $B M P R 2$, and $A C V R 1$ in this study by sequencing. It is also possible that alternate methods of inactivation of MADH4 and BMPRIA account for some cases. In a subset of hereditary non-polyposis colorectal cancer cases, the effects of subtle mutations affecting splicing or exonic duplication were not realised until separation of alleles was accomplished in somatic cell hybrid lines. ${ }^{53}$ It has also been shown that single nucleotide polymorphisms within a gene may cause increased or reduced expression of that gene and be inherited in a Mendelian fashion. ${ }^{54}$ At present, it is unclear whether the JP phenotype results specifically from altered BMP signal transduction or disruption of other TGF- $\beta$ superfamily mediated pathways. The discovery of new JP genes, careful analysis of JP cases for alternate methods of MADH4 and BMPRIA inactivation, and gene expression studies of juvenile polyps will be important in order to define the underlying genetic basis of JP.

\section{ACKNOWLEDGEMENTS}

Thanks are due to Bert Vogelstein for his helpful input and guidance, and to genetic counsellors and physicians who referred patients for these studies. These include, but are not limited to: Chris Amos, June Peters, Emmanuel Lemyre, Cathy Gilpin, Karen Huelsman, Cynthia Prows, Susan Zeesman, Edward Hoffenberg, Attila Devenyi, Noelle Bodkin, Beth Conrad, Heather Hampel, Michael Hart, Lynn Howard, Inbal Kedar, Wendy Kohlman, Barbara Kunz, Andrea Kwan, Robert Youngblood, Gabriela Repetto, and Rhonda Schnur.

\section{ELECTRONIC-DATABASE INFORMATION}

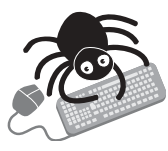

Online Mendelian Inheritance in Man (OMIM), http:// www.ncbi.nlm.nih.gov/Omim/; GenBank, http:// www.ncbi.nlm.nih.gov/Genbank/index.html; BLAST, http://www.ncbi.nlm.nih.gov/BLAST/; Primer3 Program, http://www-genome.wi.mit.edu/cgi-bin/ primer/primer3.cgi; Celera genome sequence, hitp://public.celera.com/humanpub/index.jsp

\section{Authors' affiliations}

J R Howe, M G Sayed, A F Ahmed, J Ringold, A Merg, Department of Surgery, University of lowa College of Medicine, lowa City, IA, USA 
J Larsen-Haidle, Department of Pediatrics, University of lowa College of Medicine, lowa City, IA, USA

F A Mitros, Department of Pathology, University of lowa College of Medicine, lowa City, IA, USA

C A Vaccaro, Section of Colorectal Surgery, Hospital Italiano de Buenos Aires, Buenos Aires, Argentina

G M Petersen, Department of Clinical Epidemiology, Mayo Clinic, Rochester, MN, USA

F M Giardiello, Oncology Center, Johns Hopkins University, Baltimore, MD, USA

S T Tinley, H T Lynch, Department of Preventive Medicine, Creighton University, Omaha, NE, USA

L A Aaltonen, Department of Medical Genetics, Haartman Institute, University of Helsinki, Helsinki, Finland

The generous support of the Roy J. Carver Foundation made these studies possible.

Conflict of interest: none declared.

\section{REFERENCES}

Burt RW, Bishop DT, Lynch HT, Rozen P, Winawer SJ. Risk and surveillance of individuals with heritable factors for colorectal cancer. Bull WHO 1993;68:655-64

2 Howe JR, Roth S, Ringold JC, Summers RW, Jarvinen HJ, Sistonen P, Tomlinson IPM, Houlston R, Bevan S, Mitros FA, Stone EM, Aaltonen LA. Mutations in the SMAD4/DPC4 gene in juvenile polyposis. Science 1998;280:1086-8

3 Houlston R, Bevan S, Williams A, Young J, Dunlop M, Rozen P, Eng C, Markie D, Woodford-Richens K, Rodriguez-Bigas MA, Leggett B, Neale K, Phillips R, Sheridan E, Hodgson S, Iwama T, Eccles D, Bodmer W, Tomlinson I. Mutations in DPC4 (SMAD4) cause juvenile polyposis syndrome, but only account for a minority of cases. Hum Mol Genet 1998;7:1907-12.

4 Friedl W, Kruse R, Uhlhaas S, Stolte M, Schartmann B, Keller KM, Jungck M Stern M, Loff S, Back W, Propping P, Jenne DE. Frequent 4-bp deletion in exon 9 of the SMAD4/MADH4 gene in familial juvenile polyposis patients. Genes Chromosom Cancer 1999:25:403-6.

5 Kim IJ, Ku JL, Yoon KA, Heo SC, Jeong SY, Choi HS, Hong KH, Yang SK, Park JG. Germline mutations of the dpc4 gene in Korean juvenile polyposis patients. Int J Cancer 2000;86:529-32.

6 Woodford-Richens K, Bevan S, Churchman M, Dowling B, Jones D, Norbury CG, Hodgson SV, Desai D, Neale K, Phillips RK, Young J, Leggett B Dunlop $M$, Rozen $P$, Eng C, Markie D, Rodriguez-Bigas MA, Sheridan E, Iwama T, Eccles D, Smith GT, Kim JC, Kim KM, Sampson JR, Evans G, Tejpar S, Bodmer WF, Tomlinson IP, Houlston RS. Analysis of genetic and phenotypic heterogeneity in juvenile polyposis. Gut 2000;46:656-60.

7 Sayed MG, Bair JL, Anderson ME, Riggins GJ, Petersen GM, Mitros FA, Summers RW, Lynch HT, Giardiello FM, Vogelstein B, Howe JR. The frequency of SMAD4 and PTEN mutations in juvenile polyposis. Surg Forum 2001;52:230-1.

8 Howe JR, Bair JL, Sayed MG, Anderson ME, Mitros FA, Petersen GM, Velculescu VE, Traverso G, Vogelstein B. Germline mutations of the gene encoding bone morphogenetic protein receptor 1A in juvenile polyposis. Nat Genet 2001;28:184-7.

9 Zhou XP, Woodford-Richens K, Lehtonen R, Kurose K, Aldred M, Hampel H, Launonen V, Virta S, Pilarski R, Salovaara R, Bodmer WF, Conrad BA, Dunlop M, Hodgson SV, Iwama T, Jarvinen H, Kellokumpu I, Kim JC, Leggett B, Markie D, Mecklin JP, Neale K, Phillips R, Piris J, Rozen P, Houlston RS, Aaltonen LA, Tomlinson IP, Eng C. Germline mutations in BMPR1A/ALK3 cause a subset of cases of juvenile polyposis syndrome and of Cowden and Bannayan-Riley-Ruvalcaba syndromes. Am J Hum Genet 2001;69:704-11.

10 Friedl W, Uhlhaas S, Schulman K, Stolte M, Loff S, Back W, Mangold E, Stern M, Knaebel H-P, Sutter C, Weber R, Pistorius S, Burger B, Propping P. Juvenile polyposis: massive gastric polyposis is more common in MADH4 mutation carriers than in BMPRIA mutation carriers. Hum Genet 2002;111:108-11.

11 Bevan S, Woodford-Richens K, Rozen P, Eng C, Young J, Dunlop M, Neale K, Phillips R, Markie D, Rodriguez-Bigas M, Leggett B, Sheridan E, Hodgson S Iwama T, Eccles D, Bodmer W, Houlston R, Tomlinson I. Screening SMADI, SMAD2, SMAD3, and SMAD5 for germline mutations in juvenile polyposis syndrome. Gut 1999:45:406-8.

12 Roth S, Sistonen P, Salovaara R, Hemminki A, Loukola A, Johansson M Avizienyte E, Cleary KA, Lynch P, Amos Cl, Kristo P, Mecklin JP, Kellokumpu I, Jarvinen $\mathrm{H}$, Aaltonen LA. SMAD genes in juvenile polyposis. Genes Chromosomes Cancer 1999;26:54-61.

13 Deng Z, Morse JH, Slager SL, Cuervo N, Moore KJ, Venetos G, Kalachikov S, Cayanis E, Fischer SG, Barst RJ, Hodge SE, Knowles JA. Familial primary pulmonary hypertension (gene PPH1) is caused by mutations in the bone morphogenetic protein receptor-II gene. Am J Hum Genet 2000;67:737-44.

14 Johnson DW, Berg JN, Baldwin MA, Gallione CJ, Marondel I, Yoon S-J, Stenzel TT, Speer M, Pericak-Vance MA, Diamond A, Guttmacher AE, Jackson CE, Attisano L, Kucherlapati R, Porteous MEM, Marchuk DA. Mutations in the activin receptor-like kinase I gene in hereditary haemorrhagic telangiectasia type 2. Nat Genet 1996;13:189-95

15 Berg JN, Gallione CJ, Stenzel T,, Johnson DW, Allen WP, Schwartz CE, Jackson CE, Porteous ME, Marchuk DA. The activin receptor-like kinase 1 gene: genomic structure and mutations in hereditary hemorrhagic elangiectasia type 2. Am J Hum Genet 1997;61:60-7.

16 Cox KL, Frates RC Jr, Wong A, Gandhi G. Hereditary generalized juvenile polyposis associated with pulmonary arteriovenous malformation. Gastroenterology 1980:78:1566-70.

17 Conte WJ, Rotter JI, Schwartz AG, Congleton JE. Hereditary generalized juvenile polyposis, arteriovenous malformations and colonic carcinoma. Clin Res 1982;30:93A

18 Baert AL, Casteels-Van Daele M, Broeckx J, Wiindaele L, Wilms G Eggermont E. Generalized juvenile polyposis with pulmonary arteriovenous malformations and hypertrophic osteoarthropathy. Am J Roentgenol 1983; 141:661-2

19 Jass JR, Williams CB, Bussey HJR, Morson BC. Juvenile polyposis-a precancerous condition. Histopathology 1988;13:619-30.

20 Miller SA, Dykes DD, Polesky HF. A simple salting out procedure for extracting DNA from nucleated cells. Nucleic Acids Res 1988;16:1215.

21 Consortium IHGS. Initial sequencing and analysis of the human genome. Nature 2001:409:860-921.

22 Venter JC, Adams MD, Myers EW, Li PW, Mural RJ, Sutton GG, Smith HO, Yandell M, Evans CA, Holt RA, Gocayne JD, Amanatides P, Ballew RM, Huson DH, Wortman JR, Zhang Q, Kodira CD, Zheng XH, Chen L, Skupski M, Subramanian G, Thomas PD, Zhang J, Gabor Miklos GL, Nelson C, Broder S Clark AG, Nadeau J, McKusick VA, Zinder N, Levine AJ, Roberts RJ, Simon M, Slayman C, Hunkapiller M, Bolanos R, Delcher A, Dew I, Fasulo D, Flanigan M, Florea L, Halpern A, Hannenhalli S, Kravitz S, Levy S, Mobarry C Reinert K, Remington K, Abu-Threideh J, Beasley E, Biddick K, Bonazzi V, Brandon R, Cargill M, Chandramouliswaran I, Charlab R, Chaturvedi K, Deng Z, Di Francesco V, Dunn P, Eilbeck K, Evangelista C, Gabrielian AE, Gan W, Ge W, Gong F, Gu Z, Guan P, Heiman TJ, Higgins ME, Ji RR, Ke Z, Ketchum KA, Lai Z, Lei Y, Li Z, Li J, Liang Y, Lin X, Lu F, Merkulov GV, Milshina N, Moore HM, Naik AK, Narayan VA, Neelam B, Nusskern D, Rusch DB, Salzberg S, Shao W, Shue B, Sun J, Wang Z, Wang A, Wang X, Wang J, Wei $M$, Wides R, Xiao $C$, Yan $C$, Yao A, Ye J, Zhan $M$, Zhang W, Zhang $H$, Zhao Q, Zheng L, Zhong F, Zhong W, Zhu S, Zhao S, Gilbert D, Baumhueter S, Spier G, Carter C, Cravchik A, Woodage T, Ali F, An H, Awe A, Baldwin D, Baden H, Barnstead M, Barrow I, Beeson K, Busam D, Carver A, Center A, Cheng ML, Curry L, Danaher S, Davenport L, Desilets R, Dietz S, Dodson K, Doup L, Ferriera S, Garg N, Gluecksmann A, Hart B Haynes J, Haynes C, Heiner C, Hladun S, Hostin D, Houck J, Howland T, Ibegwam C, Johnson J, Kalush F, Kline L, Koduru S, Love A, Mann F, May D McCawley S, Mclntosh T, McMullen I, Moy M, Moy L, Murphy B, Nelson K, Pfannkoch C, Pratts E, Puri V, Qureshi H, Reardon M, Rodriguez R, Rogers YH Romblad D, Ruhfel B, Scott R, Sitter C, Smallwood M, Stewart E, Strong R, Suh E, Thomas R, Tint NN, Tse S, Vech C, Wang G, Wetter J, Williams S, Williams M, Windsor S, Winn-Deen E, Wolfe K, Zaveri J, Zaveri K, Abril JF, Guigo R, Campbell MJ, Sjolander KV, Karlak B, Kejariwal A, Mi H, Lazareva B, Hatton T, Narechania A, Diemer K, Muruganujan A, Guo N, Sato S, Bafna V, Istrail S, Lippert R, Schwartz R, Walenz B, Yooseph S, Allen D, Basu A, Baxendale J, Blick L, Caminha M, Carnes-Stine J, Caulk P, Chiang YH, Coyne M, Dahlke C, Mays A, Dombroski M, Donnelly M, Ely D, Esparham S, Fosler C, Gire H, Glanowski S, Glasser K, Glodek A, Gorokhov M, Graham K, Gropman B, Harris M, Heil J, Henderson S, Hoover J, Jennings D, Jordan C, Jordan J, Kasha J, Kagan L, Kraft C Levitsky A, Lewis M, Liu X, Lopez J, Ma D, Majoros W, McDaniel J, Murphy S Newman M, Nguyen T, Nguyen N, Nodell M, Pan S, Peck J, Peterson M, Rowe W, Sanders R, Scott J, Simpson M, Smith T, Sprague A, Stockwell T, Turner R, Venter E, Wang M, Wen M, Wu D, Wu M, Xia A, Zandieh A, Zhu X The sequence of the human genome. Science 2001;291:1304-51.

23 Sayed MG, Ahmed AF, Ringold JC, Anderson ME, Bair JL, Mitros FA, Lynch HT, Petersen GM, Giardiello FM, Vogelstein B, Howe JR. Germline SMAD4 or BMPR1A mutations and phenotype of juvenile polyposis. Ann Surg Oncol 2002;9:901-6.

24 Pasche B, Kolachana P, Nafa K, Satagopan J, Chen YG, Lo RS, Brener D, Yang D, Kirstein L, Oddoux C, Ostrer H, Vineis P, Varesco L, Jhanwar S, Luzzatto L, Massague J, Offit K. TbetaR-I(6A) is a candidate tumor susceptibility allele. Cancer Res 1999;59:5678-82.

25 Markowitz S, Wang J, Myeroff L, Parsons R, Sun L, Lutterbaugh J, Fan RS, Zborowska E, Kinzler KW, Vogelstein B. Inactivation of the type II TGF-beta receptor in colon cancer cells with microsatellite instability. Science 1995;268:1336-8.

26 Thiagalingam S, Lebauer C, Leach FS, Schutte M, Hahn SA, Overhauser J, Willson SA, Markowitz S, Hamilton SR, Kern SE, Kinzler KW, Vogelstein B. Evaluation of candidate tumour suppressor genes on chromosome 18 in colorectal cancers. Nat Genet 1996;13:343-6.

27 Heldin C-H, Miyazono K, Ten Dijke P. TGF- $\beta$ signaling from cell membrane to nucleus through SMAD proteins. Nature 1997;390:465-71

28 Lagna G, Hata A, Hemmati-Brivanlou A, Massague J. Partnership between DPC4 and SMAD proteins in TGF- $\beta$ signalling pathways. Nature 1996;383:832-6

29 Zhou S, Zawel L, Lengauer C, Kinzler KW, Vogelstein B. Characterization of human FAST-1, a TGF- $\beta$ and activin signal transducer. Mol Cell 1998;2:121-7.

30 Sachatello CR, Hahn IL, Carrington CB. Juvenile gastrointestinal polyposis in a female infant: report of a case and review of the literature of a recently recognized syndrome. Surgery 1974;75:107-14

31 Howe JR, Shellnut J, Wagner B, Ringold JC, Sayed MG, Ahmed AF, Lynch PM Amos Cl, Sistonen P, Aaltonen LA. Common deletion of SMAD4 in juvenile polyposis is a mutational hotspot. Am J Hum Genet 2002;70:1357-62.

32 Takagi $Y$, Kohmura H, Futamura M, Kida H, Tanemura H, Shimokawa K, Saii S. Somatic alterations of the DPC4 gene in human colorectal cancers in vivo. Gastroenterology 1996;111:1369-72. 
33 Dennler S, Itoh S, Vivien D, ten Dijke P, Huet S, Gauthier JM. Direct binding of Smad3 and Smad4 to critical TGF beta-inducible elements in the promoter of human plasminogen activator inhibitor-type 1 gene. EMBO J 1998; 17:3091-100

34 Moren A, Itoh S, Moustakas A, Dijke P, Heldin CH. Functional consequences of tumorigenic missense mutations in the amino-terminal domain of Smad4. Oncogene 2000;19:4396-404

35 Dai JL, Bansal RK, Kern SE. G1 cell cycle arrest and apoptosis induction by nuclear Smad4/Dpc4: phenotypes reversed by a tumorigenic mutation. Proc Natl Acad Sci U S A 1999;96:1427-32.

36 Jones JB, Kern SE. Functional mapping of the MHI DNA-binding domain of DPC4/SMAD4. Nucleic Acids Res 2000;12:2363-8.

37 de Caestecker MP, Yahata T, Wang D, Parks WT, Huang S, Hill CS, Shioda T, Roberts $A B$, Lechleider RJ. The Smad4 activation domain (SAD) is a prolinerich, p300-dependent transcriptional activation domain. J Biol Chem 2000;275:2115-22.

38 Mehra A, Wrana JL. TGF-b and the Smad signal transduction pathway. Biochem Cell Biol 2002;80:605-22.

39 Hahn SA, Shutte M, Shamsul Hoque ATM, Moskaluk CA, da Costa LT, Rozenblum E, Weinstein CL, Fischer A, Yeo CJ, Hruban RH, Kern SE. DPC4, a candidate tumor suppressor gene at human chromosome 18q21.1. Science 1996;271:350-3.

40 Schutte M, Hruban RH, Hedrick L, Cho KR, Nadasdy GM, Weinstein CL, Bova GS, Isaacs WB, Cairns P, Nawroz H, Sidransky D, Casero RA Meltzer PS, Hahn SA, Kern SE. DPC4 in various tumor types. Cancer Res 1996;56:2527-30.

41 MacGrogan D, Pegram M, Slamon D, Bookstein R. Comparative mutational analysis of DPC4 (Smad4) in prostatic and colorectal carcinomas. Oncogene 1997:15:1111-4.

42 Dai JL, Turnacioglu KK, Schutte M, Sugar AY, Kern SE. Dpc4 transcriptional activation and dysfunction in cancer cells. Cancer Res 1998;58:4592-7.

43 Shi Y, Hata A, Lo RS, Massague J, Pavletich NP. A structural basis for mutational inactivation of the tumor suppressor Smad4. Nature 1997;388:87-93.

44 Johnson DW, Berg JN, Baldwin MA, Gallione CJ, Marondel I, Yoon SJ, Stenzel TT, Speer M, Pericak-Vance MA, Diamond A, Guttmacher AE, Jackson CE, Attisano L, Kucherlapati R, Porteous ME, Marchuk DA. Mutations in the activin receptor-like kinase 1 gene in hereditary haemorrhagic telangiectasia type 2. Nat Genet 1996;13:189-95.

45 Ramirez RO, Sokol RJ, Hays T, Silverman H. Case report: familial occurrence of cavernous transformation of the portal vein. Pediatr Gastroenterol Nutr $1995 \cdot 21: 313-8$.

46 Gallione CJ, Repetto GM, Legius E, Ruastgi AK, Schelley SL, Dunlop M, Mitchell G, Drouin E, Westermann CJ, Marchuk DA. Mutations in SMAD4 cause a combined hereditary hemorrhagic telangiectasia-juvenile polyposis syndrome. Am J Hum Genet 2003;73:A248.

47 Lynch ED, Ostermeyer EA, Lee MK, Arena JF, Ji H, Dann J, Swisshelm K Suchard D, MacLeod PM, Kvinnsland S, Gjertsen BT, Heimdal K, Lubs H, Moller $P$, King $M-C$. Inherited mutations in PTEN that are associated with breast cancer, Cowden disease, and juvenile polyposis. Am J Hum Genet 1997:61:1254-60.

48 Olschwang S, Serova-Sinilnikova OM, Lenoir GM, Thomas G. PTEN germline mutations in juvenile polyposis coli. Nat Genet 1998;18:12-4.

49 Eng C, Ji H. Molecular classification of the inherited hamartoma polyposis syndromes: clearing the muddied waters. Am J Hum Genet 1998;62:1020-2.

50 Marsh DJ, Roth S, Lunetta KL, Hemminki A, Dahia PLM, Sistonen P, Zheng Z, Caron S, van Orsouw NJ, Bodmer WF, Cottrell SE, Dunlop MG, Eccles D, Hodgson SV, Jarvinen H, Kellokumpu I, Markie D, Neale K, Phillips R, Rozen P Syngal S, Viig J, Tomlinson IPM, Aaltonen LA, Eng C. Exclusion of PTEN and 10q22-24 as the susceptibility locus for juvenile polyposis syndrome. Cancer Res 1997:57:5017-21.

51 Riggins GJ, Hamilton SR, Kinzler KW, Vogelstein B. Normal PTEN gene in juvenile polyposis. J Neg Observ Genet Oncol 1997;1:1

52 Marsh DJ, Coulon V, Lunetta KL, Rocca-Serra P, Dahia PL, Zheng Z, Liaw D, Caron S, Duboue B, Lin AY, Richardson AL, Bonnetblanc JM, Bressieux JM, Cabarrot-Moreau A, Chompret A, Demange L, Eeles RA, Yahanda AM, Fearon ER, Fricker JP, Gorlin RJ, Hodgson SV, Huson S, Lacombe D, Eng C. Mutation spectrum and genotype-phenotype analyses in Cowden disease and Bannayan-Zonana syndrome, two hamartoma syndromes with germline PTEN mutation. Hum Mol Genet 1998:7:507-15.

53 Nakagawa H, Yan H, Lockman J, Hampel H, Kinzler K, Vogelstein B, de la Chapelle A. Allele separation facilitates interpretation of potential splicing alterations and genomic rearrangements. Cancer Res 2002;62:4579-82.

54 Yan H, Yuan W, Velculescu VE, Kinzler KW, Vogelstein B. Allelic variation in human gene expression. Science 2002;297:1143. 